Received 05.08.2015 Reviewed 26.02.2016 Accepted 17.03.2016

A - study design

B - data collection

C - statistical analysis

D - data interpretation

$\mathbf{E}$ - manuscript preparation

F - literature search

\section{An assessment of crop water deficits of the plants growing on the Małopolska Upland (Poland)}

\section{Agnieszka KOWALCZYK ${ }^{1) A B C D}$, Leszek LABĘDZKI ${ }^{2) A B C D F}$, Antoni KUŹNIAR ${ }^{1) \text { ABDEF }}$, Marek KOSTUCH ${ }^{1) \text { BCD }}$}

\footnotetext{
1) Institute of Technology and Life Sciences at Falenty, Lesser Poland Research Centre in Kraków, Ułanów 21B, 31-450 Kraków, Poland; e-mail: a.kowalczyk@itp.edu.pl

${ }^{2)}$ Institute of Technology and Life Sciences at Falenty, Kuyavian-Pomeranian Research Centre in Bydgoszcz, Poland; e-mail: 1.labedzki@itp.edu.pl
}

For citation: Kowalczyk A., Łabędzki L., Kuźniar A., Kostuch M. 2016. An assessment of crop water deficits of the plants growing on the Małopolska Upland (Poland). Journal of Water and Land Development. No. 29 p. 11-22. DOI: $10.1515 /$ jwld-2016-0008.

\begin{abstract}
The problem of water scarcity is unfavourable for the economy, with the most significant water deficits felt by agriculture. In Poland water deficits in agriculture are occurring more frequently, causing losses in yield, not only in the Lowland areas but also in the Uplands. This paper presents an assessment of the water deficits at various excedance probability levels for four varieties of field crop and for soil types with various water retention capacity, which occur in the Małopolska Upland. Calculations were performed by balancing the amount of available soil water in the root zone. The study was based on the meteorological data from the Institute of Meteorology and Water Management for the years 1971-2010. Daily precipitation data from six rainfall stations: Borusowa, Igołomia, Książ Wielki, Miechów, Olewin and Sielec was utilised as well as average decadal air temperature, water vapour pressure, wind speed and sunshine hours from the meteorological station at Kraków-Balice. The water deficits at an excedance probability level of $20 \%$ fluctuated during the growing season from $5 \mathrm{~mm}$ (Phaeozems) to $190 \mathrm{~mm}$ (Leptosols). In the Małopolska Upland in soils with a medium capacity to retain water (110-160 mm), water deficits have occurred even in years of average rainfall (with probability $50 \%$ ). This study confirms the considerable impact of the high variability of the soil and pluvial conditions in the region on the water deficits of the field crops.
\end{abstract}

Key words: available soil water, crop water deficits, Małopolska Upland, plants

\section{INTRODUCTION}

According to Kondracki's physical and geographical division [KONDRACKI 2011] the Małopolska Upland is located in the central part of the Polish Highlands and is diverse in terms of terrain e.g., the Miechowska Upland and Proszowice Plateau (Fig. 1.)

The majority of the uplands reach an altitude of 200-300 m a.s.l. but in the area of the Holy Cross Mountains reach an elevation in excess of $600 \mathrm{~m}$ a.s.l. The Małopolska Upland is characterised by diverse climatic conditions. The weather for the greater part of the year is controlled by polar-marine and polarcontinental air. The northern and central part of the region experiences moderate climate with a long growing season and the most intense solar radiation in Poland. The average annual air temperature in the region varies from 7 to $8^{\circ} \mathrm{C}$ and the average annual precipitation ranges from 550 to $650 \mathrm{~mm}$ [DYNOWSKA, MACIEJEWSKI 1991]. Precipitation amount determines the surplus or deficit of water for agricultural production. Although throughout the region in aver- 


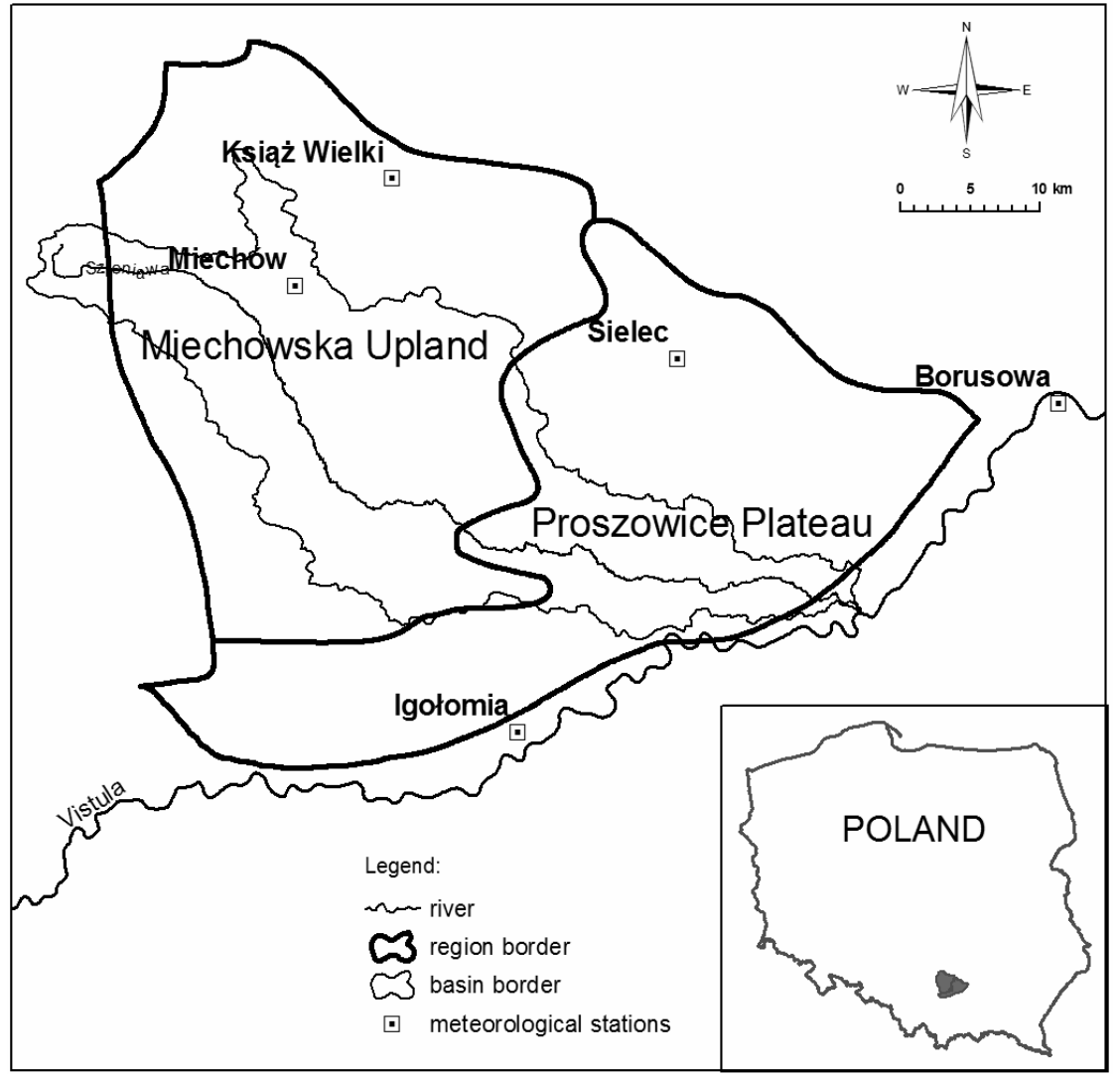

Fig. 1. Map of the Małopolska Upland (the Miechowska Upland and the Proszowice Plateau) and a layout of analysed meteorological stations; source: own elaboration

age years there are no long-term water deficits, in dry years crop losses have been recorded due to scarcity of water in the soil [KOWALCZYK et al. 2014]. Precipitation deficits are defined as the difference between crop demand for water and rainfall throughout the growing season or certain stages of growth and development [ŁABĘDZKI et al. 2008; RZEKANOWSKI et al. 2011; ŻARSKI, DUDEK 2009]. KACA et al. [2011] found that in Poland there was a clear documented trend of rising air temperatures and decreasing precipitation, which proves to be quite visible climate change. One of the negative effects of the observed changes in climate is ever more frequent water deficits and droughts. Concurrently, many decades of decreasing water balance are observed in the agricultural landscape in many European countries [KĘDZIORA et al. 2014]. According to FABER [2002] based on the monitoring of the Crop Growth Monitoring System CGMS (used in Europe for forecasting yields) and applying the WOFOST model (used to simulate the growth and development of the plants) the water deficit in Poland limits the yield potential of wheat cultivation by $46.9 \%$, of spring barley by $42.9 \%$, of winter rapeseed by $60 \%$ and of potatoes by $58.9 \%$. In Poland research in the field of crop water deficits are numerous, as evidenced by many publications [BINIAK et al. 2007; CHMURA 2001; DMOWSKI, DZIEŻYC 2009; DMOWSKI et al. 2002; 2008; DZIEŻYC 1988; DZIEŻYC et al. 1980; 1986; 1987a, b; DZIEŻYC, NOWAK 1992; NyC, PoKŁADEK 2009; PANASIEWICZ, KOZIARA 2007;
PANEK 1993]. In the all above studies to assess the water needs of the plants, the method of optimal precipitation was used. Optimal precipitation is the amount of rain needed to grow plants from seed, or beginning of the growing season, until the end harvest of mature plants. CHMURA [2001] analysed indicators of optimal precipitation and water needs of selected crops (cereals, root crops and legumes) and found that both deficits and surpluses of rainfall had an adverse impact on the yield. Yield reductions (caused by deficits and surpluses respectively) were estimated to be: for cereals by $2-27 \%$ and $3-21 \%$; for potatoes by $4-45 \%$ and $3-30 \%$; for sugar beet of $2-43 \%$ and $14-$ $19 \%$, for fodder beet by $16-73$ and $73 \%$ and $8-28 \%$, for pulses of $5-42 \%$ and $21-40 \%$.

In addition to the method of optimal precipitation in determining crop water deficits the methodology of RoGUSKI et al. [1988] was applied, which takes into account the amount of easily available water in the soil. Soil water retention significantly affects the size of the estimated water deficits and the accuracy of forecasting the amount of water needed for irrigation. Following this methodology ŁABĘDZKI [1996] identified water deficits for the selected field crops and grasslands in 49 provinces in Poland to assess the likely water scarcity in crop production. The author relied on a balance sheet equation that takes into account: precipitation, crop potential evapotranspiration and the readily available soil water in the root zone. New opportunities to improve deficit forecasting for 
particular arable crops were presented with the establishment of a soil-mapping database at the Institute for Land Reclamation and Grassland Farming [OSTROWSKI 1996] and the creation of a procedure for determining the isolines (isohyets) of the water deficits, along with advances in computer cartographic visualization. The implementation of this project, as part of a computerized system of spatial information, created opportunities for the development of a set of maps marking estimated water deficits for growing major crops at a given yield, taking into account the soils on which the cultivation of these plants have justification. OSTROWSKI et al. [2008] produced an atlas presenting spatial variability of the water deficits for selected crops and grasslands, in conjunction with soils occurring on the Polish territory and indicating the regions where there is a need for irrigation.

Taking into account soil water that can be useful for plants is indispensable to estimate water deficits of cropped plants. Soil water balance is a commonly accepted and widely used method. The FAO approach based on a simple soil water balance model CROPWAT accounts for soil moisture content and meteorological parameters [PEREIRA et al. 1995; 2003; SMITH 1992a; TEIXEIRA, PEREIRA 1992]. The mostly used standard approach is based on the FAO guidelines to estimate crop water requirement [ALLEN et al. 1998]. There are many papers devoted to water deficits of crop plants. CRAMER and PRENTICE [1988] developed a simple deterministic simulation model for landscape-scale soil water deficits. The simple soil water balance was used which estimates soil water deficit at a scale suitable for comparison with the distributions of plant species and soil types. KNOX et al. [1996], taking into account crop, climate, and soil factors, developed a procedure for mapping the spatial distribution of water demands for potatoes in England and Wales using a geographic information system (GIS). THOMAS [2000] estimated water deficits and their multi-year trends for field crops in China using the soil water balance. TAO et al. [2003; 2009] analysed agricultural water demands and deficits in China using a crop-soil-water balance model developed by SMITH [1992a, b]. JONES [2007] states that the indirect estimation of water status on the basis of soil moisture balance calculation is widely adopted, especially for agronomic and irrigation purposes.

The aim of the presented work was to evaluate the water deficits of varying excedance probability levels for four crop species (sugar beet, grain maize, wheat and late grown potatoes) and for the five soil types, with different water retention capacity, that occur in the Małopolska Upland.

\section{MATERIAL AND METHODS}

Research was carried out for the crop water deficits of four species of plants: sugar beet, late-grown potato, grain maize and winter wheat. The five soil types (IUSS working group WRB 2006) with varying water retention availability that occur in the Małopolska Upland were considered [IUSS Working Group WRB 2006; PTG 2011]. They were: Rendzic Leptosols, Haplic Phaeozems - silt, Haplic Luvisols and Dystric Cambisols - light loamy sands, Haplic Luvisols and Eutric Cambisols - loess, Eutric Fluvisols heavy loams and silts (Tab. 1).

Table 1. Soil types according to IUSS Working Group WRB [2006], and their water retention

\begin{tabular}{|c|c|c|c|}
\hline No. & $\begin{array}{c}\text { The WRB reference } \\
\text { soil groups }\end{array}$ & $\begin{array}{l}\text { Classification by } \\
\text { the Polish Soil } \\
\text { Society (PTG) }\end{array}$ & $\begin{array}{c}\text { The total available } \\
\text { soil water in the } \\
\text { 1-m soil profile } \\
T A S W \text { acc. to } \\
\text { WALCZAK et al. } \\
\text { mm }\end{array}$ \\
\hline 1 & $\begin{array}{l}\text { Rendzic Leptosols } \\
\text { (pure) }\end{array}$ & rendzina & 72 \\
\hline 2 & $\begin{array}{l}\text { Haplic Phaeozems - } \\
\text { silt }\end{array}$ & black earths & 270 \\
\hline 3 & $\begin{array}{l}\text { Haplic Luvisols and } \\
\text { Dystric Cambisols - } \\
\text { light loamy sands }\end{array}$ & $\begin{array}{l}\text { brown and podso- } \\
\text { lic soils originated } \\
\text { from sands }\end{array}$ & 111 \\
\hline 4 & $\begin{array}{l}\text { Haplic Luvisols and } \\
\text { Eutric Cambisols - } \\
\text { loess }\end{array}$ & $\begin{array}{l}\text { brown and fawn } \\
\text { soils made of loess }\end{array}$ & 255 \\
\hline 5 & $\begin{array}{l}\text { Eutric Fluvisols - } \\
\text { heavy loams and silts }\end{array}$ & \begin{tabular}{|l|} 
alluvial soils, \\
medium and heavy
\end{tabular} & 158 \\
\hline
\end{tabular}

Sources: own studies based on the data from IUSS Working Group WRB [2006], PTG [2011] and WALCZAK et al. [2002].

The study was based on meteorological data provided by the Institute of Meteorology and Water Management for the years 1971-2010. Data included daily rainfall data from six stations (Borusowa, Igołomia, Książ Wielki, Miechów, Olewin and Sielec) and decadal averages of air temperature, water vapour pressure, wind speed and sunshine hours taken from the meteorological station at Kraków-Balice. The Mann-Kendall method (MK) was used to test water deficits trends in the region [DRAPELA, DRAPELOVA 2011]. Software used for performing the statistical Mann-Kendall test is XLSTAT 2016.

Crop water deficits arise when water demand is not fully covered by rainfall and the available soil water in the root zone. Deficiencies may indicate a need for net irrigation to be applied to achieve high yields. The demand of crop water (water needs) is the amount of water needed to achieve a certain production level (of a specified final yield). A measure of demand for water by a particular crop, need to issue a specific crop, is the potential evapotranspiration of the plant $\left(E T_{p}\right)$. Potential evapotranspiration is the actual evapotranspiration expected under conditions of sufficient water supply to the plant. This is the amount of water consumed by the plant to produce certain yields in a particular state of development, fertilized at a certain level, under the circumstances of climate, soil and habitat. It is assumed that the conditions of plant development and nutrient supply are good. 
Crop water deficit is the amount of water that is needed to meet crop water demand $\left(E T_{p}\right)$ after deduction of precipitation and current water readily available soil water for plants [DOORENBOS, KASSAM 1979]. Crop water deficits were calculated using an available soil water balance computation for the root zone, according to the methodology presented by ALLEN et al. [1998]. The root zone is presented as a container in which the water content may change. For the criterion of the water deficit the exhaustion of readily available soil water was adopted, i.e., such conditions that there is inhibition of the growth of plants. Water deficit $(N)$ in each decade of the vegetation period from April 1, is calculated according to the equations: when $E T_{p}^{t} \leq P^{t}$

$$
N^{t}=0
$$

when $E T_{p}^{t}>P^{t}$ and $A S W_{p}^{t}>(1-p) T A S W$

$$
N^{t}=E T_{p}^{t}-P^{t}-\left[A S W_{p}^{t}-(1-p) T A S W\right]
$$

when $E T_{p}^{t}>P^{t}$ and $A S W_{p}^{t} \leq(1-p) T A S W$

$$
N^{t}=E T_{p}^{t}-P^{t}
$$

where $N^{t}$ is the crop water deficit in the decade $t, E T_{p}^{t}$ is the potential evapotranspiration in the decade $t, P^{t}$ is the precipitation total in the decade $t, A S W_{p}{ }^{t}$ is the available soil water in the root zone at the beginning of the decade $t, T A S W$ is the total available soil water in the root zone, $p$ is a coefficient of water availability (dimensionless). All variables, except $p$, are expressed in millimetres.

Total available soil water $T A S W$ is calculated as:

$$
T A S W=S W C_{P P W}-S W C_{W T W}
$$

where $S W C_{P P W}$ is the soil water content at the field water capacity $(\mathrm{p} F=2.2)$ and $S W C_{W T W}$ is the soil water at the moisture state of permanent wilting $(\mathrm{p} F=$ $4.2)$, both in millimetres. These soil water contents and $T A S W$ were estimated for the $10 \mathrm{~cm}$ layers of the $100 \mathrm{~cm}$ soil profile on the basis of data given by WALCZAK et al. [2002].

The coefficient of water availability $p$ determines the fraction of $T A S W$ that a crop can extract from the root zone without suffering water stress. It depends on the growth phase of a plant and the depth of root penetration. For the performed computations, coefficient $p$ for selected plants were taken from DooREnBos, PRUITT [1977] and ŁABĘDZKI [2006].

Available soil water at the beginning of the decade is calculated using a water balance equation:

$$
A S W_{p}^{t}=A S W_{k}^{t-1}=A S W_{p}^{t-1}+P^{t-1}-E T_{p}^{t-1}
$$

where $A S W_{k}^{t-1}$ and $A S W_{p}^{t-1}$ are available soil water in a root zone at the end and at the beginning of the decade $t-1$, respectively, $P^{t-1}$ is precipitation in the decade $t-1, E T_{p}^{t-1}$ is the potential evapotranspiration in the decade $t-1$. All variables are measured in millimetres.

Potential evapotranspiration $E T_{p}$ is calculated using a crop-factor method as:

$$
E T_{p}=k_{c} E T_{o}
$$

where $E T_{p}$ is the potential evapotranspiration in $\mathrm{mm}$, $E T_{o}$ is the reference evapotranspiration in $\mathrm{mm}$ and $k_{c}$ is the crop factor. Reference evapotranspiration was calculated from the Penman-Monteith equation [ALLEN et al. 1998; ŁABĘDZKI et al. 2011; 2014]:

$$
E T_{o}=\frac{0.408 \Delta R_{n}+\gamma \frac{900}{T+273} u\left(e_{s}-e_{a}\right)}{\Delta+\gamma(1+0.34 u)}
$$

where $E T_{o}$ is the reference evapotranspiration in $\mathrm{mm} \cdot$ day $^{-1}, R_{n}$ is net radiation in $\mathrm{MJ} \cdot \mathrm{m}^{-2} \cdot$ day $^{-1}, T$ is mean daily air temperature at $2 \mathrm{~m}$ height in ${ }^{\circ} \mathrm{C}, u$ is wind speed at $2 \mathrm{~m}$ height in $\mathrm{m} \cdot \mathrm{s}^{-1}, \Delta$ is the slope of the vapour pressure curve in $\mathrm{kPa} \cdot{ }^{\circ} \mathrm{C}^{-1}, \gamma$ is the psychrometric constant in $\mathrm{kPa}^{\circ} \mathrm{C}^{-1}, e_{a}$ is the actual vapour pressure in $\mathrm{kPa}$ and $e_{s}$ is the saturation vapour pressure in $\mathrm{kPa}$.

Crop factor $k_{c}$ depends on the growth phase of a plant and on crop yield. In this study values of this coefficient, adjusted to reference evapotranspiration calculated by Penman-Monteith method, were taken from OSTROWSKI et al. [2008], which were estimated according to ALLEN et al. [1998].

Calculations of changes in available soil water according to equation (5) were performed for the decades (10-days periods) using the mean decadal values of meteorological parameters $T, R_{n}, u$ and $e_{a}$ and the decadal sum of precipitation $P$. Changes in available soil water were calculated for temporally variable depth of the root zone. At present, detailed data on the growth of root system in various field crops are missing. Therefore, mean increment of the root zone depth equal $10 \mathrm{~mm} \cdot \mathrm{d}^{-1}$ up to the maximum depth in complete plant development was adopted in the computations. For deep-rooted plants $(>100 \mathrm{~cm})$ calculations were performed to the depth of active layer no deeper than $100 \mathrm{~cm}$.

Calculations of crop water deficits were performed for ten-day periods between 1971 and 2010 . Sums for both months and the whole vegetation period (April-September) were calculated as a sum of the ten-day values. Monthly and growing season water deficits of a given exceedance probability were determined as percentiles.

In the applied method and model there are several assumptions that are the limitations of the method. Making the balance of each year starts with the as- 
sumption that the soil water content is near field water capacity and is equal to the total available soil water $T A S W$. The simple procedure assumes that the infiltration of daily precipitation to the root zone is within the same day and that the time of deep percolation from the root zone when soil water content exceeds field capacity is also 1 day. In the water balance the root zone is presented by means of a container not supplied with water by capillary rise. Its share in covering the demands of evapotranspiration and in supplementing water reserves in the root zone depends on the soil type, the depth of the water table, the wetness of the root zone, the difference of water potential in particular soil layers and on conductive soil properties. The amount of water transported upwards by capillary rise from the water table to the root zone and the input of capillary water from deeper layers to the present root zone due to the difference in soil water potential are assumed to be zero. The assumption is made that the water table is more than $1 \mathrm{~m}$ below the bottom of the root zone. Moreover, the crop factor method used for calculate evapotranspiration also has certain limitations. Using crop factors $k_{\mathrm{c}}$ gives good estimation of evapotranspiration under average meteorological conditions. When weather conditions are extreme the evapotranspiration values can be less reliable and burdened with higher error.
For the above reasons the water deficits calculated with Eqs. (1)-(3) should be dealt with as the reference deficits pertaining to a soil profile not deeper than $100 \mathrm{~cm}$ and the assumed water conditions as well as to crop plants of high yield feasible at intensive fertilisation and unlimited access to other yield-forming factors. When plants may use water accumulated in soil layers deeper than $100 \mathrm{~cm}$, the deficits might be smaller. This is also true for the period, when the root zone is shallower than $100 \mathrm{~cm}$ but fed with water inputs from deeper soil layers by capillary rise. The deficits will also be smaller for final crop yields smaller than assumed.

\section{RESULTS AND DISCUSSION}

The Małopolska Upland is considered to be the land of Silesian-Cracow climate. According to the humidity criteria this plateau belongs to wet agro climate (C) with a climatic water balance of -40 to +60 $\mathrm{mm}$ [BAC et al. 1993]. Average rainfall during the growing season for the years 1971-2010 (Sielec station) was $430.7 \mathrm{~mm}$. A minimum amount of 282.5 $\mathrm{mm}$ was recorded in 1992 and a maximum of 695.2 $\mathrm{mm}$ in 2010 (Fig. 2). In this paper examples are given of the results for the five types of soils: a view as to the size of the crop water deficits the region.

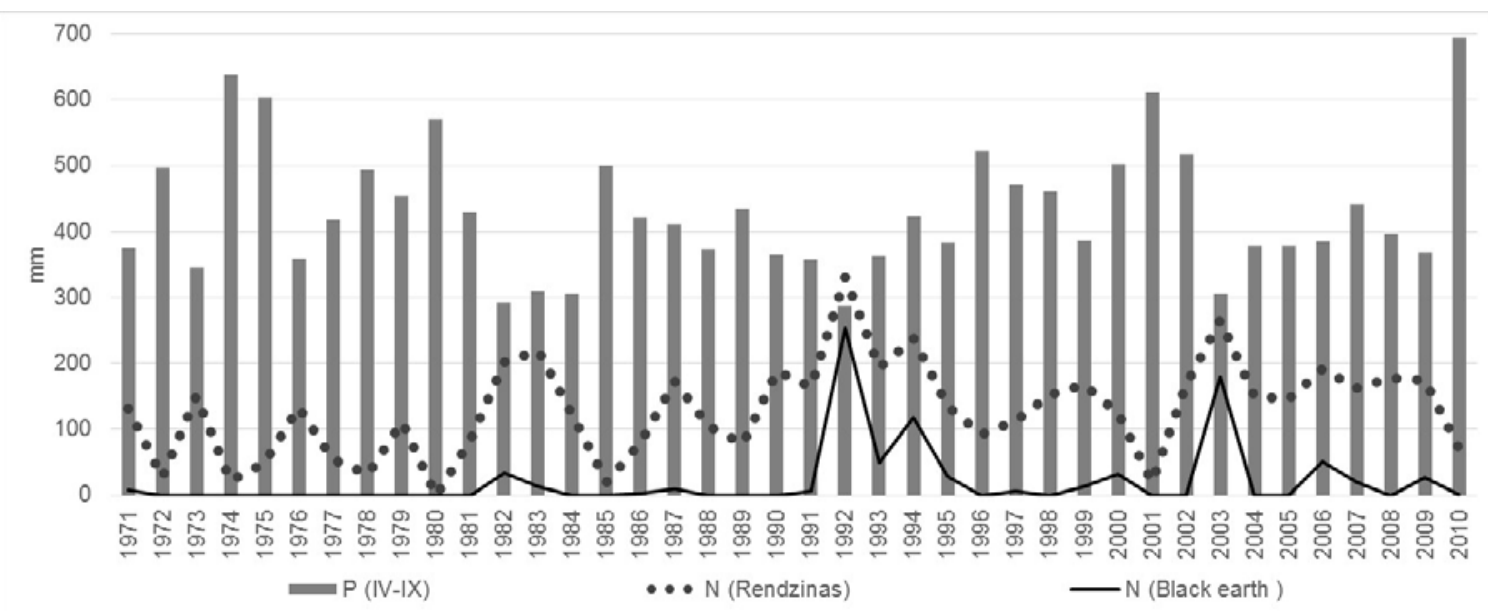

Fig. 2. Precipitation totals $P(\mathrm{~mm})$ during the growing seasons (April-September) and the crop water deficit $N(\mathrm{~mm})$ for the period 1971-2010 of sugar beet on the soils: Haplic Luvisols and Eutric Cambisols - loess and Haplic Phaeozems - silt (Sielec station); source: own study

Sugar beet. The crop water deficits during the growing season (with a probability of $20 \%$ ) ranged from 4.8 (Haplic Phaeozems - silt) to $149.0 \mathrm{~mm}$ (Rendzic Leptosols, pure) (Tab. 2, Fig. 2). The largest ten-day water deficit occurred in July 2006 and reached $59 \mathrm{~mm}$ (Haplic Luvisols and Dystric Cambisols - light loamy sands) (Fig. 3). For Haplic Phaeozems - silt the largest deficiency, of $39 \mathrm{~mm}$, occurred in the first ten days of August 2003 (Fig. 3). According to OsTROWSKI et al. [2008], in this region sugar beet water deficits on the Haplic Phaeozems - silt soils are $0-40 \mathrm{~mm}$ at an exceedance probability of 20 and $50 \%$. It follows that in this region, on this type of soil with a large storage of available soil water $(270$ $\mathrm{mm})$, the probability of a water deficiency for sugar beet is low $(<20 \%)$. The water deficits of sugar beets growing on the Haplic Luvisols and Dystric Cambisols tend to increase (Fig. 4).

There were significant relationships between the water deficits of sugar beet and rainfall during the growing season (April-September) for Eutric Fluvisols (Fig. 5). The high dependence was found not only from the weather conditions, but also from the soil conditions. 
Table 2. The crop water deficits of specific probabilities (50\% and 20\%) during the period 1971-2010 for selected plants grown on the typical soils in the Małopolska Upland

\begin{tabular}{|c|c|c|c|c|c|c|c|c|c|c|}
\hline \multirow[b]{3}{*}{$\begin{array}{l}\text { Meteorological } \\
\text { station }\end{array}$} & \multicolumn{10}{|c|}{ Probability } \\
\hline & \multicolumn{5}{|c|}{$50 \%$} & \multicolumn{5}{|c|}{$20 \%$} \\
\hline & $\begin{array}{l}0 \\
0 \\
0 \\
0 \\
0 \\
0 \\
0 \\
0 \\
0 \\
0 \\
0 \\
0 \\
0 \\
0 \\
0 \\
0\end{array}$ & 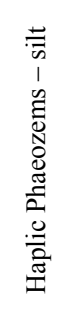 & 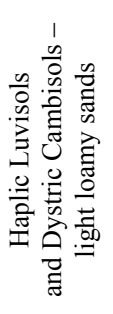 & 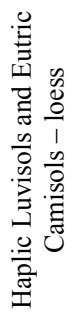 & 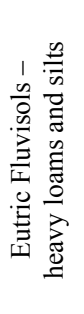 & $\begin{array}{l}0 \\
0 \\
0 \\
0 \\
0 \\
0 \\
0 \\
0 \\
0 \\
0 \\
0 \\
0 \\
0 \\
0 \\
0 \\
0\end{array}$ & 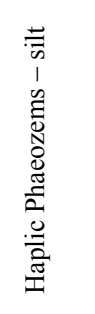 & 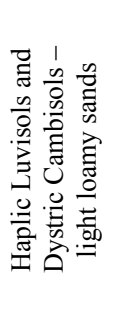 & 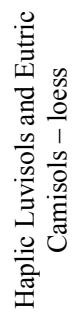 & 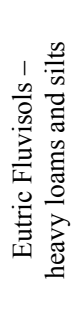 \\
\hline \multicolumn{11}{|c|}{ Sugar beet } \\
\hline Borusowa & 149.0 & 0.3 & 134.3 & 3.2 & 89.7 & 195.4 & 44.2 & 194.0 & 65.4 & 155.8 \\
\hline Igołomia & 113.5 & 0.0 & 94.9 & 0.0 & 62.0 & 188.1 & 22.4 & 168.4 & 43.8 & 145.1 \\
\hline Książ Wielki & 131.4 & 0.1 & 111.9 & 2.8 & 87.0 & 189.9 & 37.7 & 188.7 & 63.3 & 165.8 \\
\hline Miechów & 111.5 & 0.0 & 89.0 & 0.0 & 41.5 & 169.6 & 13.6 & 159.5 & 30.4 & 128.0 \\
\hline Olewin & 97.0 & 0.0 & 54.5 & 0.0 & 7.5 & 137.8 & 4.8 & 119.9 & 14.4 & 89.3 \\
\hline Sielec & 134.2 & 0.0 & 115.6 & 3.5 & 64.6 & 180.5 & 26.8 & 172.4 & 38.8 & 139.1 \\
\hline \multicolumn{11}{|c|}{ Late-grown potatoes } \\
\hline Borusowa & 114.5 & 44.9 & 111.8 & 53.6 & 97.2 & 156.2 & 92.8 & 149.5 & 99.9 & 135.8 \\
\hline Igołomia & 89.5 & 44.2 & 86.7 & 52.0 & 79.6 & 130.9 & 83.9 & 130.0 & 91.8 & 118.1 \\
\hline Książ Wielki & 103.4 & 47.7 & 99.5 & 59.7 & 86.2 & 151.3 & 106.1 & 149.2 & 114.2 & 144.5 \\
\hline Miechów & 79.9 & 24.0 & 78.3 & 33.9 & 65.2 & 139.6 & 88.8 & 136.4 & 97.5 & 130.5 \\
\hline Olewin & 59.6 & 6.2 & 57.7 & 12.5 & 46.2 & 111.6 & 79.1 & 108.2 & 84.4 & 101.6 \\
\hline Sielec & 106.8 & 36.7 & 106.3 & 49.9 & 89.7 & 139.7 & 90.3 & 138.2 & 96.3 & 130.0 \\
\hline \multicolumn{11}{|c|}{ Grain maize } \\
\hline Borusowa & 82.6 & 0.0 & 48.8 & 0.0 & 6.3 & 134.4 & 0.5 & 98.7 & 3.0 & 41.8 \\
\hline Igołomia & 68.3 & 0.0 & 30.4 & 0.0 & 0.8 & 121.2 & 0.0 & 87.6 & 1.0 & 29.1 \\
\hline Książ Wielki & 77.7 & 0.0 & 51.5 & 0.0 & 9.8 & 146.3 & 0.2 & 116.4 & 2.7 & 50.7 \\
\hline Miechów & 49.3 & 0.0 & 18.6 & 0.0 & 3.1 & 117.3 & 0.2 & 81.4 & 2.1 & 22.8 \\
\hline Olewin & 27.0 & 0.0 & 5.2 & 0.0 & 0.0 & 92.2 & 0.0 & 66.4 & 0.0 & 13.4 \\
\hline Sielec & 68.0 & 0.0 & 33.1 & 0.0 & 5.2 & 120.1 & 1.4 & 94.7 & 2.9 & 35.7 \\
\hline \multicolumn{11}{|c|}{ Winter wheat } \\
\hline Borusowa & 70.0 & 0.0 & 36.4 & 0.0 & 0.7 & 105.0 & 0.0 & 88.2 & 0.0 & 53.4 \\
\hline Igołomia & 52.9 & 0.0 & 24.4 & 0.0 & 1.2 & 107.7 & 0.0 & 94.8 & 0.0 & 45.1 \\
\hline Książ Wielki & 68.6 & 0.0 & 51.0 & 0.0 & 7.5 & 111.8 & 0.0 & 107.1 & 0.0 & 56.2 \\
\hline Miechów & 60.7 & 0.0 & 32.2 & 0.0 & 0.0 & 94.7 & 0.0 & 81.9 & 0.0 & 41.1 \\
\hline Olewin & 31.4 & 0.0 & 8.6 & 0.0 & 0.0 & 66.7 & 0.0 & 48.2 & 0.0 & 9.4 \\
\hline Sielec & 56.7 & 0.0 & 27.4 & 0.0 & 1.5 & 105.7 & 0.0 & 103.2 & 0.0 & 71.0 \\
\hline
\end{tabular}

Source: own study.

Results of the Mann-Kendall test indicate: H0there is no trend in the series and hypothesis ( $\mathrm{Ha})$ follows a trend in the series. As the computed $p$-value is lower than the significance level alpha $=0.05$, one should reject the null hypothesis $\mathrm{H} 0$, and accept the alternative hypothesis Ha. The risk to reject the null hypothesis $\mathrm{H} 0$ while it is true is lower than $1.58 \%$.

For sugar beet grown on brown and podsolic soils $(T A S W=111 \mathrm{~mm})$ the largest water deficits $(160-192$ $\mathrm{mm}$ for probability $20 \%$ ) were observed in the areas of the rainfall stations Borusowa and Książ Wielki (Fig. 6). The smallest water deficits for those probabilities are near Olewin (124 mm). On Haplic Luvisols and Eutric Cambisols $(T A S W=255 \mathrm{~mm})$, the largest water deficit of sugar beet $(64 \mathrm{~mm}$ with a probability of $20 \%$ ) occur in the vicinity of the Borusowa station and deficiencies of the $36-38 \mathrm{~mm}$ cover the central regions. The smallest values occur in areas around Olewin station $(16 \mathrm{~mm})$.
Late-grown potatoes. The water deficits (with a probability of $20 \%$ ) of late-grown potatoes in the growing season ranged from $79 \mathrm{~mm}$ (Haplic Phaeozems) to $156 \mathrm{~mm}$ (Haplic Luvisols and Eutric Cambisols) (Tab. 1). According to OSTROWSKI et al. [2008] the Małopolska Upland soils are not suited to the cultivation of potatoes but late-grown potatoes are cultivated there. OSTROWSKI et al. [2008] show that in the analysed region the water deficit, with a probability of $50 \%$ (corresponding to average rainfall for the study area) amount to $80-120 \mathrm{~mm}$ in the Haplic Luvisols and Eutric Cambisols and on Haplic Luvisols and Dystric Cambisols.

Late-grown potatoes grown on Haplic Luvisols and Dystric Cambisols and soil formed from poorly loamy and loamy sands $(T A S W=111 \mathrm{~mm})$ display the largest water deficits (148 $\mathrm{mm}$ with a probability of $20 \%$ ) in the vicinity of the Borusowa station, while the water deficit in the order of $130 \mathrm{~mm}$ occur in the 
a)

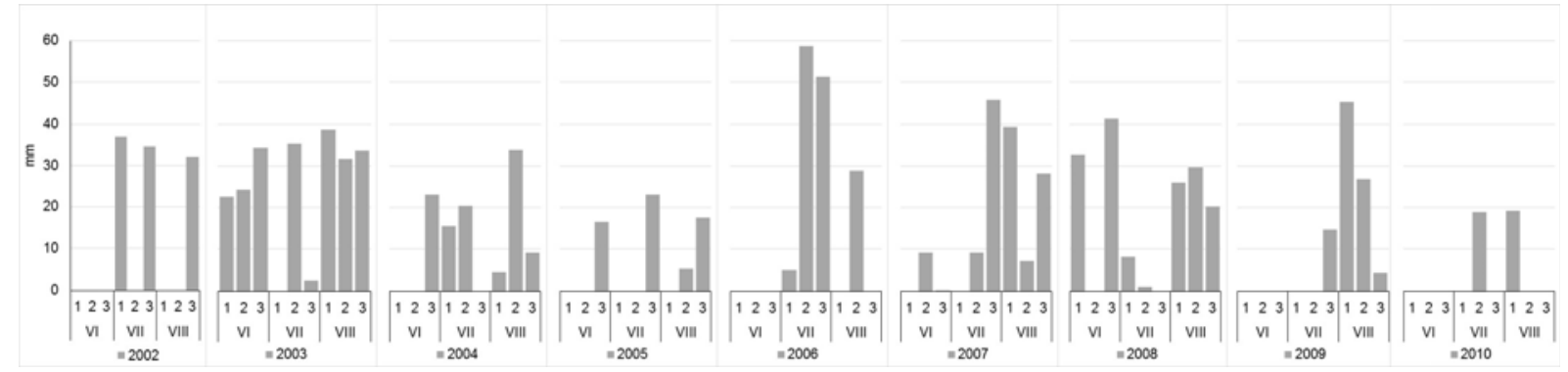

b)

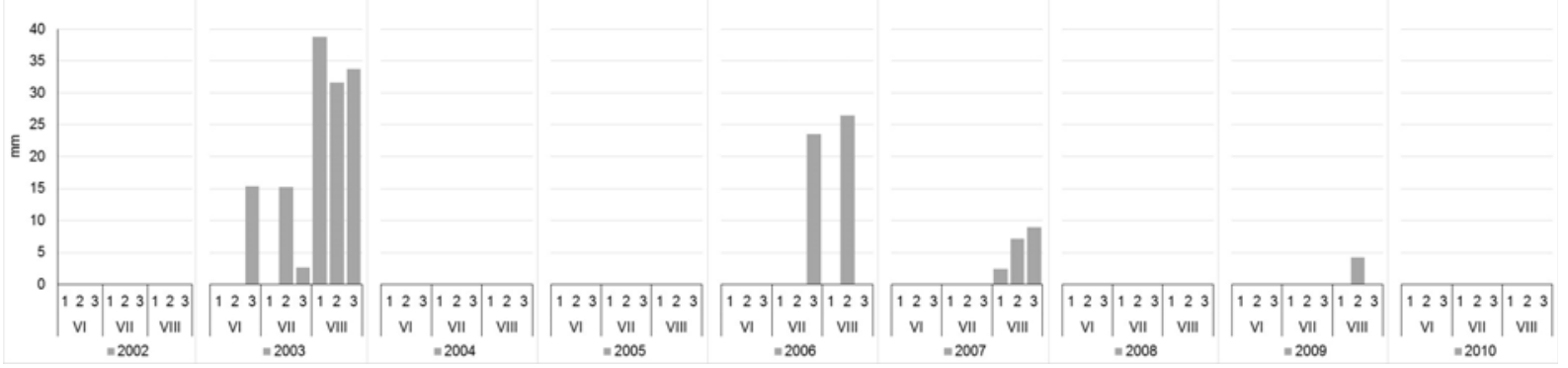

c)

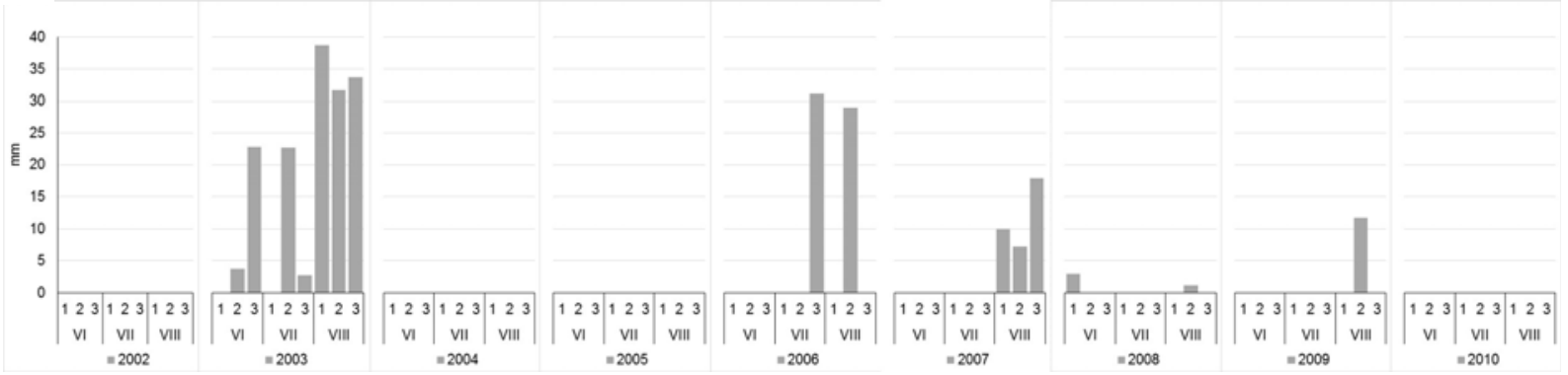

Fig. 3. Ten-day water deficits (mm) for sugar beet for the period 2002-2010 (during June-August) on the soils: a) Haplic Luvisols and Dystric Cambisols (total available soil water $-T A S W=111 \mathrm{~mm})$, b) Haplic Phaeozems $(T A S W=270 \mathrm{~mm})$,

c) Haplic Luvisols and Eutric Cambisols $(T A S W=255 \mathrm{~mm})$ (Sielec station); source: own study

Mann-Kendall trend test / Two-tailed test:

\begin{tabular}{|l|r|}
\hline Kendall's tau & 0.268 \\
\hline$S$ & 208.000 \\
\hline $\operatorname{Var}(S)$ & 7358.000 \\
\hline$p$-value (two-tailed) & 0.016 \\
\hline alpha & 0.050 \\
\hline
\end{tabular}

\begin{tabular}{|c|c|c|c|c|c|c|c|}
\hline Variable & Observations & $\begin{array}{c}\text { Observations with } \\
\text { missing data }\end{array}$ & $\begin{array}{c}\text { Observations without } \\
\text { missing data }\end{array}$ & Minimum & Maximum & Mean & $\begin{array}{c}\text { Standard } \\
\text { deviation }\end{array}$ \\
\cline { 4 - 7 } & & 0 & 40 & 0.000 & 326.210 & 112.969 & 78.815 \\
\hline
\end{tabular}

Fig. 4. Results of the Mann-Kendall test, the water deficits for sugar beet for the period 1971-2010 on Haplic Luvisols and Dystric Cambisols (Sielec station); source: own study 
a)

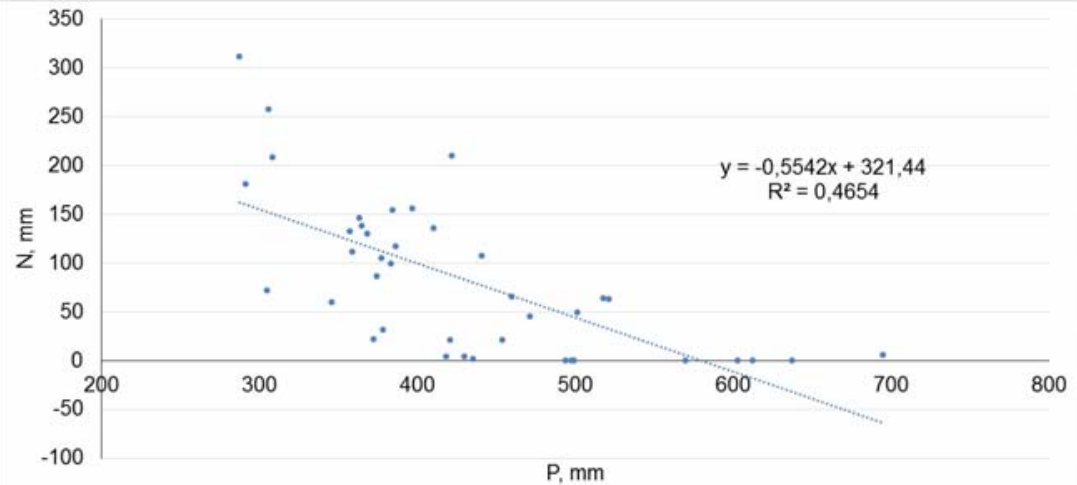

b)

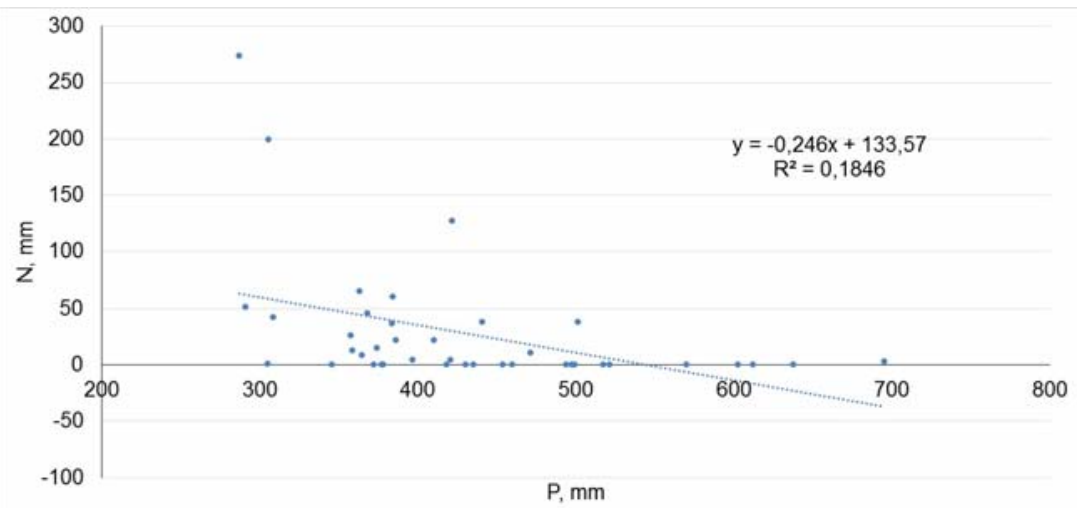

c)

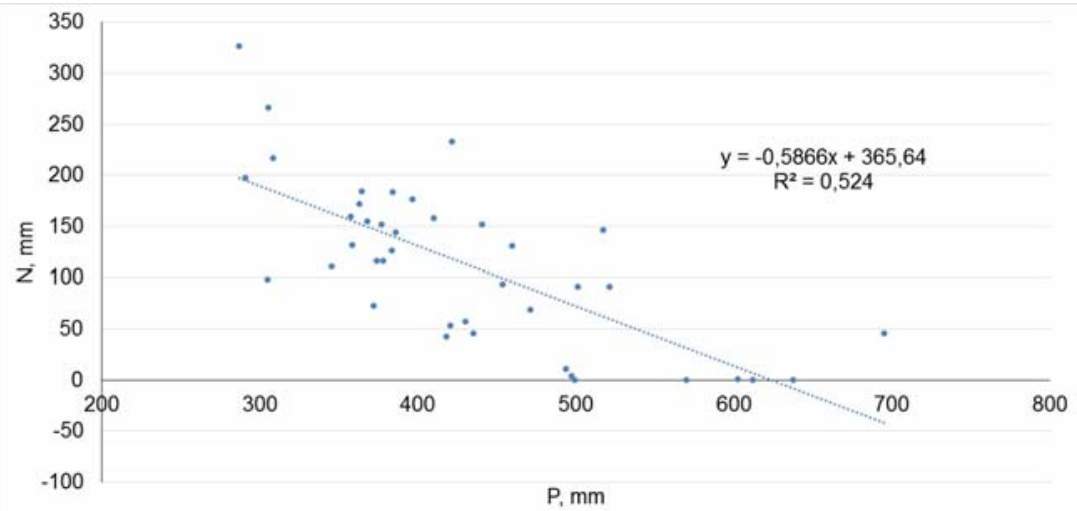

Fig. 5. Relationship between the crop water deficits of sugar beet and precipitation during the growing season (April-September) for the period 1971-2010 for the soils: a) Eutric Fluvisols, b) Haplic Luvisols and Dystric Cambisols, c) Haplic Luvisols and Eutric Cambisols (Sielec station); source: own study

a)

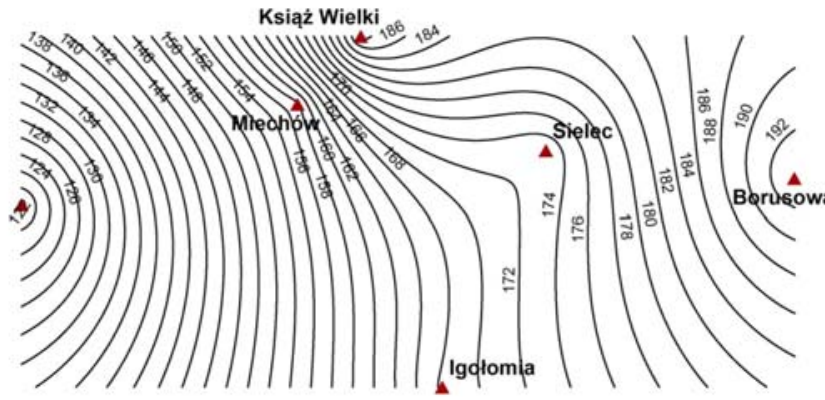

b)

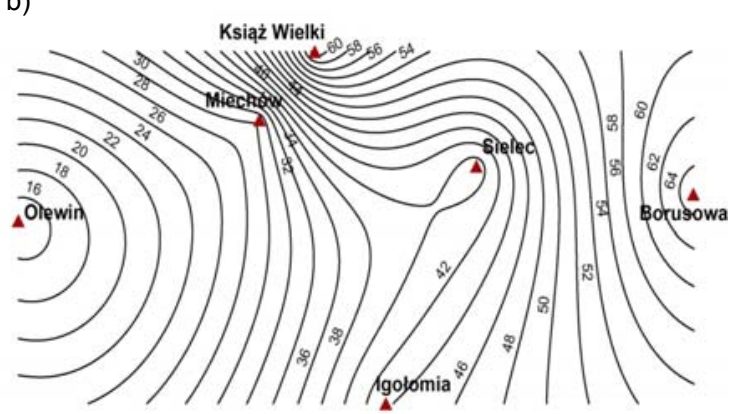

Fig. 6. The isolines of water deficits for sugar beet $(\mathrm{mm})$ at the $20 \%$ probability level on the soils a) Haplic Luvisols and Dystric Cambisols (total available soil water $-T A S W=111 \mathrm{~mm}$ ), b) Haplic Luvisols and Eutric Cambisols $(T A S W=255 \mathrm{~mm})$; source: own study 

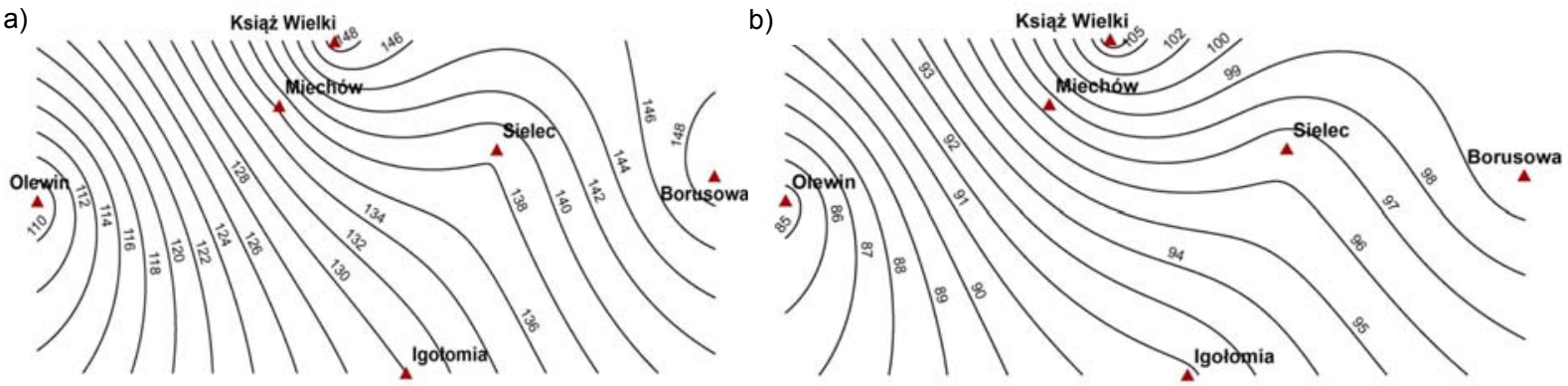

Fig. 7. The isolines of water deficits for late-grown potatoes $(\mathrm{mm})$ of the $20 \%$ probability level on the soil: a) Haplic Luvisols and Dystric Cambisols (total available soil water - TASW $=111 \mathrm{~mm}$ ), b) Haplic Luvisols and Eutric Cambisols $(T A S W=255 \mathrm{~mm})$; source: own study

central regions. Slightly smaller values occur in the areas around Olewin (Fig. 7). On Haplic Luvisols and Eutric Cambisols $(T A S W=255 \mathrm{~mm})$ diversity of the water deficits of late-grown potatoes, for the probability of $20 \%$, is low: the $100-105 \mathrm{~mm}$ values include the northern part of the upland (Książ-Miechów) and $87-90 \mathrm{~mm}$ values are located in the western region. The smallest deficits, with a probability of $20 \%$, occur in the western part of the region (Fig. 7).

Grain maize. The water deficits (with a probability of $20 \%$ ) almost did not occur on the Haplic Phaeozems $(T A S W=270 \mathrm{~mm})$ and on the Haplic Luvisols and Eutric Cambisols $(T A S W=255 \mathrm{~mm})$. The largest deficits occurred in the Rendzic Leptosols (pure) of the smallest water capacity $(T A S W=72 \mathrm{~mm})$ and amounted to about $146 \mathrm{~mm}$. These results are confirmed on maps provided by OSTROWSKI et al. [2008]. These maps show that in the analysed area the water deficits, with a probability of $50 \%$ (corresponding to average rainfall for the study period), do not exceed $40 \mathrm{~mm}$.

Winter wheat. In the analysed region no deficit of water was identified for the winter wheat grown on the Haplic Phaeozems. On the alluvial soils deficiencies (20\% probabilities) ranged from 9.4 to $71 \mathrm{~mm}$. On the Rendzic Leptosols (pure) such deficiencies ranged up to $108 \mathrm{~mm}$ (Tab. 1). According to OsTROWSKI et al. [2008] in this region the water deficit, with a probability of $50 \%$ (corresponding periods average in terms of rainfall), are about $40 \mathrm{~mm}$ on Rendzic Leptosols (pure) but do not occur on other analysed soil types. The water deficits were not identified in terms of average rainfall years - as suggested in previous studies - which suggests that, in years of typical rainfall, irrigation of winter wheat is not necessary on the light and medium soils in the this region [ŻARSKI 2006].

\section{CONCLUSIONS}

On the Małopolska Upland soils, which are characterised by a medium retention capacity, the water deficits of sugar beets and potato crops occurred even in years of average rainfall (with probability 50\%). The water deficit of sugar beet during the growing season ranged from $48 \mathrm{~mm}$ (black earth soils) to 148 mm (Rendzic Leptosols (pure)). The largest deficit throughout the analysed period $(232.8 \mathrm{~mm})$, which occurred while rainfall was lowest, was recorded in Rendzic Leptosols in 1992 around the Sielec station.

The largest water deficits, in the analysed upland, were identified in crops of sugar beet and late-grown potatoes. For the same crop seasonal water deficits on the lighter soils (Rendzic Leptosols) are considerably larger compared to Haplic Luvisols and Eutric Cambisols. These results confirm those of earlier studies that identified no need for irrigation in the region, on both heavy and light soils.

Maps of the water deficit isoclines may be useful in determining the water needs of field crops in conditions that ensure, in term of water availability, the achievement of maximum yields. It also permits the determination of the water deficits for irrigation planning with reliability $(20 \%, 50 \%)$ for each soil type.

The water deficits of the field crops specified in this large-scale study can be used as a comprehensive indicator of soil-plant-climate for planning water and economic development in the Małopolska Upland.

\section{REFERENCES}

Allen R.G., Pereira L.S., Raes D., Smith M. 1998. Crop evapotranspiration: Guidelines for computing crop water requirements. FAO Irrigation and Drainage Paper. No. 56. Rome. FAO. ISBN 92-5-104219-5 pp. 300.

BAC S., KoźMIŃSKI C., RoJeK M. 1993. Agrometerologia [Agrometeorology]. Warszawa. Wydaw. Nauk. PWN. ISBN 83-01111-14-3 pp. 248.

BiniAK M., KostrZEWA S., ŻYromsKi A. 2007. Uwarunkowania termiczne $\mathrm{i}$ opadowe potrzeb nawadniania $\mathrm{w}$ rejonie Wrocławia na przykładzie pszenicy jarej [Thermal and rainfall conditioning of the irrigation needs in the Wrocław region for example of winter wheat]. Zeszyty Problemowe Postępów Nauk Rolniczych. Z. 526 p. 3751.

Chmura K. 2001. Przyrodnicze i agrotechniczne uwarunkowania uprawy ziemniaka $\mathrm{w}$ południowozachodniej Polsce [Natural and agrotechnical conditioning of potato cultivation in southern-western Poland]. Zeszyty Naukowe AR we Wrocławiu. Rozprawy. T. 180. Z. 410 pp. 109.

Cramer W., Prentice I.C. 1988. Simulation of regional soil moisture deficits on a European scale. Norwegian Journal of Geography. Vol. 42 (2-3) p. 149-151. 
DMOWSKi Z., DZIEŻYC H. 2009. Potrzeby opadowe pszenicy jarej na glebach kompleksów pszennego dobrego i żytniego bardzo dobrego w północno-wschodniej Polsce [Rainfall requirements of winter wheat on the complex of a good wheat soils and on the very good rye soils in northern-eastern Poland]. Acta Agrophysica. Vol. 13. Nr 1 p. 39-48.

DMowski Z., DZIEŻyc H., NowaK L. 2008. Ocena wpływu wybranych parametrów opadu i gleby na plonowanie pszenicy jarej w rejonie południowo-zachodnim Polski. [Impact assessment of selected rainfall parameters and the soils in the southern-western region of Poland]. Acta Agrophysica. Vol. 11. Nr 3 p. 613-623.

DMOWSKi Z., NowaK L., KRUHLAK A. 2002. Wpływ deszczowania, gęstości sadzenia i zróżnicowanego nawożenia mineralnego na wysokość i jakość plonu ziemniaka [The impact of sprinkling, planting density and mineral fertilisation on quantity and quality of the potato field]. Zeszyty Problemowe Postępów Nauk Rolniczych. Z. 489 p. 239-247.

DOORENBOS J., KASSAM A.H. 1979. Yield response to water. FAO Irrigation and Drainage Paper. No. 33. Rome. FAO pp. 176.

DoOREnBOS J., PRUITT W.O. 1977. Guidelines for predicting crop water requirements. FAO Irrigation and Drainage Paper. No. 52. Rome. FAO. ISBN 92-5-400279-8. pp. 156.

Drapela K., Drapelova I. 2011. Application of MannKendall test and the Sen's slope estimates for trend detection in deposition data from Bílý Kříž (Beskydy Mts., the Czech Republic) 1997-2010. Beskdy Mendel University in Brno. Vol. 4. Iss. 2 p. 133-146.

Dynowska I., MACIEJeWSKi M. 1991. Dorzecze Górnej Wisły [The Upper Vistula River Basin]. Cz. 1. Ed. I. Dynowska. Warszawa-Kraków. PWN. ISBN 83-0110317-5 pp. 341.

DZIEŻYC J. 1988. Rolnictwo w warunkach nawadniania [Agriculture under irrigation]. Warszawa. PWN. ISBN 83-01081-21-X pp. 414.

DZIEŻyC J., BIESZCZAD S., DMOWSKi Z., DZIEŻyCowa D., NowAK L., PANEK K. 1980. Wskaźniki spadku plonów wskutek niedoboru i nadmiaru opadów w krainie Wielkich Dolin [The indicators of the yield decrease as a result of a deficit and surplus of precipitation in the land of the Great Valleys]. Zeszyty Problemowe Postępów Nauk Rolniczych. Melioracje. T. 23. Z. 128 p. 45-55.

Dzieżyc J., DMOWski Z., Nowak L., PANeK K. 1986. Modele oceny strat $\mathrm{w}$ produkcji polowej wskutek niedoboru opadów [Assessment models of the losses in the field production as a result of rainfall deficits]. Zeszyty Problemowe Postępów Nauk Rolniczych. Z. 268 p. 186204.

DZIEŻYC J., NowAK L. 1992. Wpływ nawodnienia deszczownianego na produkcje polową [The impact of sprinkler irrigation on the field production]. Roczniki Akademii Rolniczej w Poznaniu. R. 234 p. 5-15.

DZIEŻyC J., NowaK L., PANEK K. 1987a. Dekadowe wskaźniki potrzeb opadowych roślin uprawnych w Polsce [The decade indicators of the rainfall needs of the crops cultivated in Poland]. Zeszyty Problemowe Postępów Nauk Rolniczych. Z. 314 p. 11-33.

DZIEŻYC J., NOWAK L., PANEK K. 1987b. Średnie regionalne niedobory opadów i potrzeby deszczowania roślin uprawnych na glebach lekkich i średnich [Average regional rainfall deficits and sprinkling requirements of the crops grown on the light and medium soils]. Zeszyty
Problemowe Postępów Nauk Rolniczych. Z. 314 p. 3547.

FABER A. 2002. Środowiskowe uwarunkowania produkcji roślinnej w Polsce i Europie według symulacji CGMS [Environmental conditions of the crop production in Poland and Europe according to the CGMS simulations]. Pamiętniki Puławskie. Z. 130(1) p. 137-151.

IUSS Working Group WRB 2006. World reference base for soil resources. 2nd ed. World Soil Resources Reports. No. 103. Rome. FAO. ISBN 92-5-105511-4 pp. 132.

JONES H.G. 2007. Monitoring plant and soil water status: established and novel methods revisited and their relevance to studies of drought tolerance. Journal of Experimental Botany. Vol. 58. Iss. 2 p. 119-130.

KACA E., ŁabęDZKi L., LubBE J. 2011. Gospodarowanie wodą $\mathrm{w}$ rolnictwie $\mathrm{w}$ obliczu ekstremalnych zjawisk pogodowych [Water management in agriculture the face of extreme weather events]. Postępy Nauk Rolniczych. Nr 1 p. 37-49.

Kędziora A., KępińsKa-Kasprzak M., Kowalczak P., Kundzewicz Z.W., Miler A., PierzGalski E., TOKarCZYK T. 2014. Zagrożenia związane z niedoborem wody [The risks related to the water deficits]. Nauka. $\mathrm{Nr} 1 \mathrm{p}$. 149-172.

KNOX J.W., WeAtherhead E.K., Bradley R.I. 1996. Mapping the spatial distribution of volumetric irrigation water requirements for maincrop potatoes in England and Wales. Agricultural Water Management. Vol. 31. Iss. 12 p. $1-15$.

KONDRACKI J.A. 2011. Geografia regionalna Polski [Regional geography of Poland]. Warszawa. Wydaw. Nauk. PWN. ISBN 978-83-01-16022-7 pp. 444.

KowAlCZYK A., KuŹNIAR A., ŁABĘDZKi L. 2014. Bieżąca ocena potrzeb i niedoborów wodnych roślin uprawnych z zastosowaniem automatycznego monitoringu i modelowania matematycznego [Operational assessment of crop water requirements and deficits using automatic meteorological monitoring and mathematical modelling]. Problemy Inżynierii Rolniczej. Z. 2(84) s. 87-102.

ŁABĘDZKI L. 1996. Niedobory wodne upraw rolniczych jako wskaźnik potrzeb małej retencji. W: Potrzeby i możliwości zwiększania retencji wodnej na obszarach wiejskich [The crop water deficits as an indicator of small water retention needs. In: The needs and possibilities to increase water retention in the rural areas]. Materiały Seminaryjne. Nr 37. Falenty. Wydaw. IMUZ p. 34-62.

ŁABĘDZKI L. 2006. Susze rolnicze - zarys problematyki oraz metody monitorowania i klasyfikacji [Agricultural droughts - an outline of the problems and methods for monitoring and classification]. Woda-SrodowiskoObszary Wiejskie. Rozprawy Naukowe i Monografie. Nr 17. ISBN 83-88763-63-6 pp. 107.

ŁABĘDZKI L., BĄK B., KANECKA-GESZKE E., KASPERSKA-WoŁOWICZ W., SMARZYŃSKA K. 2008. Związek między suszą meteorologiczną i rolniczą w różnych regionach agroklimatycznych Polski [Relationship between meteorological and agricultural drought in different agro-climatic Polish regions]. Woda-Środowisko-Obszary Wiejskie. Rozprawy naukowe i monografie. $\mathrm{Nr}$ 25. ISBN 978-83-61875-03-1 pp. 137.

ŁABĘDZKi L., BĄK B., SMARZYŃSKa K. 2014. Spatial-temporal variability and trends of Penman-Monteith reference evapotranspiration (FAO-56) in 1971-2010 under climatic conditions of Poland. Polish Journal of Environmental Studies. Vol. 23. No. 6 p. 2083-2091. DOI: $10.15244 /$ pjoes/27816. 
ŁabęzZKi L., Kanecka-Geszke E., BaK B., SŁowińska S. 2011. Estimating reference evapotranspiration using the FAO Penman-Monteith method for climatic conditions of Poland. In: Evapotranspiration. Ed. L. Łabędzki. Rijeka. InTech. p. 275-294.

NYC K., POKŁADEK R. 2009. Eksploatacja systemów melioracyjnych podstawą racjonalnej gospodarki wodnej w środowisku przyrodniczo-rolniczym [Operation of the land drainage systems, the basis for rational use of water in the natural and agricultural environment]. Współczesne Problemy Inżynierii Środowiska. T. 14. Wrocław. Wydaw. UP we Wrocławiu. ISBN 978-83-60574-69-0 pp. 82.

OSTROWSKI J. 1996. Baza danych glebowo-kartograficznych - struktura i użytkowanie [The database of soil-mapping - the structure and operation]. Systemy informacji przestrzennej. Materiały VI Konferencji Naukowo-Technicznej. Warszawa. PTIP p. 471-480.

OstrowsKi J., ŁabęDZKi L., Kowalik W., KANECKA-GeszKe E., KaspersKa-Wolowicz W., SMARZyŃSKA K., TUSIŃSKI E. 2008. Atlas niedoborów wodnych roślin uprawnych i użytków zielonych w Polsce [Atlas of the water deficits of cultivated plants and grasslands in Poland]. Falenty. Wydaw. IMUZ pp. $19+32$ maps.

PANASIEWICZ K., KozIARA W. 2007. Plonowanie i wartość siewna ziarna pszenicy ozimej $\mathrm{w}$ zależności od uwarunkowań wodnych i sposobu uprawy roli [Yielding and seeding value of winter wheat, depending on the water conditions and the method of cultivation]. Fragmenta Agronomica. Vol. 24. Nr 4(96) p. 65-71.

PANEK K. 1993. Wpływ ilości opadów na plonowanie zbóż w zależności od poziomu nawożenia, zwięzłości gleby i rejonu uprawy [The impact of rainfall on the crop yields, depending on the fertilization level, texture of soil, and the region of cultivation]. Zeszyty Problemowe Postępów Nauk Rolniczych. Z. 314 p. 119-135.

Pereira L.S., TeOdoro P.R., RodrigueZ P.N., TeiXeIrA J.L. 2003. Irrigation scheduling simulation: The model ISAREG. In: Tools for drought mitigation in Mediterranean regions. Eds G. Rossi, A. Cancelliere, L.S. Pereira, T. Oweis, M. Shatanawi, A. Zairi. Dordrecht. Kluwer p. $161-180$.

Pereira L.S., van Den Broek B.J., Kabat P., Allen R.G. (eds) 1995. Crop-water-simulation models in practice. Wageningen Press. ISBN 907413426 pp. 339.

RoguSKI W., SARnaCKa S., DRUPKA S. 1988. Instrukcja wyznaczania potrzeb i niedoborów wodnych roślin uprawnych i użytków zielonych [Instruction for calculating the requirements and water deficits of field crops and grassland]. Materiały Instruktażowe. $\mathrm{Nr} 66$. Falenty. IMUZ pp. 90.

RZEKANOWSKi CZ., ŻARski J., RolbieCKi S. 2011. Potrzeby, efekty i perspektywy nawadniania roślin na obszarach szczególnie deficytowych w wodę [The needs, effects and prospects of crop irrigation in the areas of particular deficit of water]. Postępy Nauk Rolniczych. T. 63. Nr 1 p. 51-63.

SMITH M. 1992a. CROPWAT: A computer program for irrigation planning and management. FAO Irrigation and Drainage Paper. No. 46. Rome. FAO pp. 132.

SMITH M. 1992b. Report on the expert consultation on revision of FAO methodologies for crop water requirements. Rome. FAO pp. 54.

PTG 2011. Systematyka gleb Polski [Systematics of the Polish soils]. Roczniki Gleboznawcze. Warszawa. T. 62. Nr 3 pp. 195.

Tao F., YoKozawa M., Hayashi Y., Lin E. 2003. Changes in agricultural water demands and soil moisture in China over the last half-century and their effects on agricultural production. Agricultural and Forest Meteorology. Vol. 118. Iss. 3-4 p. 251-261.

TaO F., Yokozawa M., Zhang Z. 2009. Modelling the impacts of weather and climate variability on crop productivity over a large area: A new process-based model development, optimization, and uncertainties analysis. Agricultural and Forest Meteorology. Vol. 149. Iss. 5 p. 831-850.

TeIXEIRA J.L. PEREIRA L.S. 1992. ISAREG, an irrigation scheduling simulation model. ICID Bulletin. Vol. 41. Iss. 2 p. $29-48$.

Thomas A. 2000. Climatic changes in yield index and soil water deficit trends in China. Agricultural and Forest Meteorology. Vol. 102. Iss. 2-3 p. 71-81.

WALCZAK R., Ostrowski J. WitKowsKa-WalcZAK B., STAWIŃSKI C. 2002. Hydrofizyczne charakterystyki mineralnych gleb ornych Polski [Hydrophysical characteristics of the mineral arable soils in Poland]. Acta Agrophysica. Monogr. T. 79. ISBN 1234-4125 pp. 64.

ŻARSKI J. 2006. Potrzeby i efekty nawadniania zbóż. W: Nawadnianie roślin [The needs and the effects of irrigation on cereals In: Crop irrigation]. Ed. S. Karczmarczyk, L. Nowak. Warszawa. PWRiL p. 383-403.

ŻARSKI J., DUDEK S. 2009. Zmienność czasowa potrzeb nawadniania wybranych roślin $\mathrm{w}$ regionie Bydgoszczy. [The temporal variation of the irrigation needs of selected plants in the region of Bydgoszcz]. Infrastruktura i Ekologia Terenów Wiejskich. Nr 3 p. 141-149.

\section{Agnieszka KOWALCZYK, Leszek LABĘDZKI, Antoni KUŹNIAR, Marek KOSTUCH}

Ocena niedoborów wodnych roślin uprawianych na Wyżynie Małopolskiej

\section{STRESZCZENIE}

\section{Słowa kluczowe: niedobory wodne, retencja gleb, rośliny uprawne, Wyżyna Małopolska}

Problem niedoboru wody jest niekorzystny dla całej gospodarki, jednak najbardziej i najszybciej niedobory wody odczuwane są w rolnictwie. Na terenie Polski coraz częściej występują braki wody w rolnictwie, i nie tylko, na obszarach położonych na Niżu Polskim, powodując straty w plonach. W pracy przedstawiono ocenę niedoborów wodnych o różnym prawdopodobieństwie przewyższenia, dla czterech gatunków roślin: buraka cukrowego, kukurydzy na ziarno, pszenicy ozimej, ziemniaka późnego oraz na glebach o zróżnicowanych zdolno- 
ściach retencyjnych występujących na Wyżynie Małopolskiej. Obliczenia przeprowadzono metodą bilansowania zapasu wody użytecznej w warstwie korzeniowej gleby.

W pracy wykorzystano dane meteorologiczne Instytutu Meteorologii i Gospodarki Wodnej z lat 1971-2010 - dobowe sumy opadów z sześciu stacji (Borusowa, Igołomia, Książ Wielki, Miechów, Olewin i Sielec) oraz średnie dekadowe wartości temperatury powietrza, ciśnienia pary wodnej, prędkości wiatru i usłonecznienia ze stacji meteorologicznej Kraków-Balice.

Niedobory wody obliczono metodą bilansowania zapasu wody użytecznej w warstwie korzeniowej gleby za pomocą metody Penmana-Monteitha (ewapotranspiracja wskaźnikowa) [ALLEN et al. 1998; ŁABĘDZKI et al. 2011; 2014].

Badania potwierdziły dużą zmienność warunków glebowych i pluwialnych w tym regionie oraz ich wpływ na niedobory wodne upraw polowych. Niedobory o prawdopodobieństwie przewyższenia $20 \%$ wynosiły w okresie wegetacji od $5 \mathrm{~mm}$ (na czarnoziemach - Phaeozems) do $190 \mathrm{~mm}$ (na rędzinach - Leptosols). Na glebach Wyżyny Małopolskiej o średnich zdolnościach do retencjonowania wody $(110-160 \mathrm{~mm}$ ) niedobory wodne wystąily nawet $\mathrm{w}$ latach przeciętnych pod względem ilości opadów (o prawdopodobieństwie $50 \%$ ). W uprawie pszenicy ozimej na czarnoziemach, glebach brunatnych i madach na Wysoczyźnie Proszowickiej niedobory wody nie wystapiły. Jednocześnie niedobory wody (o prawdopodobieństwie $20 \%$ ) w uprawie ziemniaka późnego w okresie wegetacyjnym wynoszą od $106 \mathrm{~mm}$ (czarnoziemy) do $156 \mathrm{~mm}$ (rędziny). 